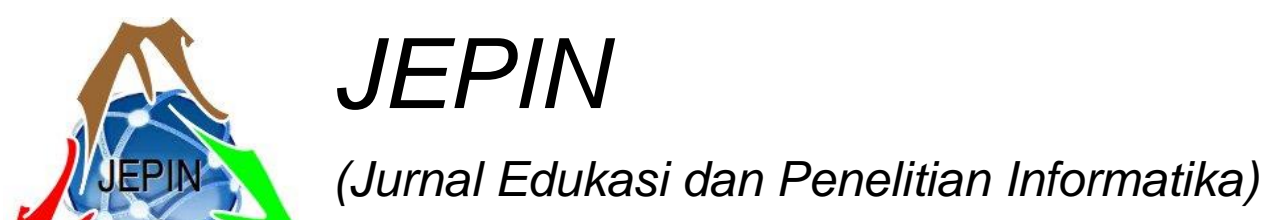

Vol. 7

No. 3

Desember

ISSN(e): 2548-9364 / ISSN(p) : 2460-0741

\title{
Pembuatan Program Aplikasi Desain Batik Flora
}

\author{
Nugroho Agus Haryono ${ }^{\# 1}$, Widi Hapsari ${ }^{\# 2}$ \\ \#Informatika, Universitas Kristen Duta Wacana \\ Jl. Wahidin SH., No. 5 - 25 Yogyakarta \\ 1nugroho@staff.ukdw.ac.id \\ ${ }^{2}$ widiestaff.ukdw.ac.id
}

\begin{abstract}
Abstrak - Batik mengalami perkembangan motif dari waktu ke waktu. Motif yang dahulu berawal dari batik klasik, saat ini menjadi sangat bervariasi. Tanaman bunga yang tumbuh pada lingkungan sekitar menimbulkan inspirasi untuk membuat motif batik Flora. Pembuatan desain batik flora secara manual dilakukan dengan membuat sketsa bunga yang menjadi inspirasi pada kertas dengan pena. Proses desain ini membutuhkan kemampuan menggambar dari desainer dan waktu yang cukup. Perkembangan teknologi informasi memberikan kesempatan untuk mengembangkan desain batik yang inovatif dengan lebih cepat. Penelitian ini bertujuan untuk membuat program aplikasi desain batik flora. Program aplikasi ini didesain dengan berdasarkan ide peneliti untuk memenuhi kebutuhan dasar desainer untuk memperoleh motif flora. Aplikasi berhasil membuat gen yang bersih dengan cara mengambil objek bunga dari sebuah foto menggunakan fitur warna. Pemotongan objek dilakukan dengan metode 8-connected labeling. Objek bunga yang diperoleh dari aplikasi dapat disimpan dan digunakan oleh aplikasi untuk membuat sebuah pheno. Aplikasi menyediakan area untuk membuat pheno dengan model posisi bebas. Satu atau dua pheno dapat digandakan dalam layout tertentu untuk menghasilkan desain kain batik flora. Aplikasi yang dibuat menyediakan 6 (enam) layout desain kain yang masih bisa diperbanyak model layoutnya dalam penelitian lanjutan. Dengan menggunakan aplikasi yang dibangun dapat dihasilkan kreasikreasi desain gen, pheno maupun kain batik flora. Variasi desain batik flora sangat bergantung dari kreasi pengguna dalam membuat gen dan pheno.
\end{abstract}

Kata kunci - batik, flora, gen, pheno, desain.

\section{PENDAhUluan}

Baju Batik sudah menjadi ciri khas dari Bangsa Indonesia. Program pemakaian baju batik pada hari-hari tertentu juga sudah dilakukan secara nasional. Kerajinan Batik Indonesia berkaitan erat dengan identitas budaya masyarakat Indonesia sebagai ekspresi kreativitas dan spritualitas melalui simbol warna dan desain. UNESCO telah mencantumkan Batik Indonesia ke dalam Daftar Representatif Warisan Budaya Manusia [1]. Batik merupakan karya seni yang memadukan seni dan teknologi yang sudah dilakukan oleh leluhur bangsa Indonesia [2]. Pemberian nama pada Batik bisa dilakukan dengan menggunakan asal daerah Batik atau pun didasarkan pada motif Batik. Motif batik atau pola batik menurut unsurunsur utamanya dibagi menjadi tiga bagian utama yaitu: Ornamen motif batik, ragam hias pengisi atau tambahan, dan Isen motif batik. Ketiga elemen motif batik tersebut merupakan satu kesatuan yang akan membentuk corak tertentu [3].
Desain Batik dapat dilakukan secara manual atau pun dengan memanfaatkan teknologi informasi. Kemajuan teknologi informasi memberikan peluang tanpa batas untuk pengembangan batik [4]. Pembuatan desain batik dapat dilakukan secara interaktif oleh desainer dengan memanfaatkan sistem-sistem desain batik interaktif, seperti sistem desain batik Truntum [5], sistem desain batik Parang [6]. Pembuatan desain batik dengan pola tertentu juga dapat dilakukan secara komputasi dengan meniru pola tertentu yang ada di alam, seperti pola dari akar tanaman [7], pola batik dari karang laut [8], dan retakan ubin [9], dengan menerapkan algoritma genetika [10], dengan menggunakan interpolasi pada sub bagian [11], dengan menerapkan geometri fraktal [12], [13], fraktal untuk desain pola butterfly [14], dan fraktal untuk pengembangan border kerancang[15], menerapkan formulasi matematika tertentu, seperti model forces random walk [16], menggunakan kurva bezier[17], komputasi matematis [18], dan model gelombang sinus [19]. Meskipun demikian, penelitianpenelitian lanjutan mengenai pembuatan sistem desain batik secara interaktif masih sangat perlu dikembangkan untuk inovasi desain.

Batik Indonesia kaya akan teknik, simbol, filosofi, dan budaya. Supriyono mengungkapan sejarah dan perkembangan batik, serta dinamika dan keterampilan membatik di berbagai daerah di Indonesia. dalam bukunya, supriyono menjelaskan cara pembuatan aneka jenis batik dan membahas berbagai tantangan dan upaya pemberdayaan industri kreatif ini, yang salah satunya adalah tantangan untuk memanfaatkan teknolog informasi dalam industri batik [20]. Pembuatan desain batik secara manual dilakukan dengan cara membuat sketsa batik pada kertas desain menggunakan pena. Hali ini memerlukan keterampilan desainer yang tinggi dan cukup waktu untuk melakukannya. Menghadapi permasalahan tersebut, maka peneliti melakukan penelitian terapan pemanfaatan teknologi informasi dalam membuat inovasi desain batik. Penelitian ini dibiayai oleh Lembaga Penelitian dan Pengabdian kepada Masyarakat (LPPM) UKDW tahun ke-4 dalam skema Riset Unggulan Universitas Multi Tahun. Penelitian terapan ini bertujuan untuk membuat sebuah program aplikasi desain batik flora. Aplikasi yang dibangun diharapkan bisa membantu para desainer untuk mendesain batik flora secara interaktif. 


\section{Metode}

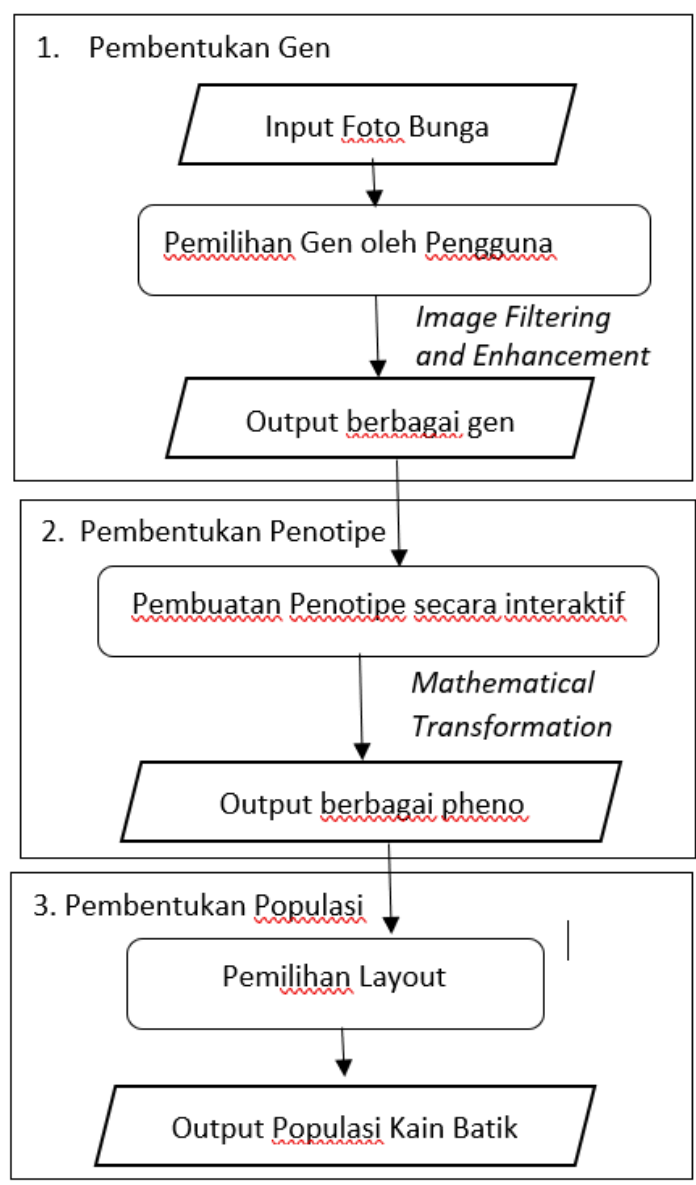

Gambar. 1 Diagram aplikasi

Penelitian terapan ini dilakukan dengan membuat program aplikasi desain batik flora. Aplikasi dikembangkan dengan menggunakan pendekatan komputasi evolusioner menggunakan ruang genotipe dan ruang phenotipe. Dalam ruang genotipe sebuah gen bisa diubah menjadi gen yang baru (mutation), demikian juga dalam ruang phenotipe sebuah pheno dapat diubah menjadi pheno yang baru (selection). Pembuatan pheno dilakukan dengan mengambil gen dari ruang genotipe (epigenesis). Aplikasi dibuat menggunakan analisis citra untuk mengenali objek yang dipilih oleh pengguna. Analisis citra dapat digunakan untuk mengenali citra melalui beberapa metode/fungsi seperti: enhancement, konversi dari suatu tipe citra mejadi tipe lainnya, labeling, dan cropping [21], menggunakan segmentation [22], dan variasi thresholding nilai biner [23]. Analisis objek pada suatu gambar dapat dilakukan dengan pendekatan warna RGB (Red, Green, and Blue) secara prosedural [24], dan menggunakan image regions [25]. Deteksi tepi objek gambar dapat dilakukan dengan menggunakan tipetipe gambar biner melalui klasterisasi seed [26], menggabungkan beberapa metode edge detector[27], dan menggunakan algortima-algoritma edge detection yang ada[28]. Aplikasi dibuat dengan memanfaatkan fitur warna untuk memperoleh objek bunga dan 8-connected labelling untuk melakukan pemotongan objek. Aplikasi didesain secara dinamis dengan input awal sistem adalah Foto bunga yang akan dipakai sebagai objek dalam motif. Aplikasi dibuat dalam tiga panel, yaitu: pembuatan gen, pembuatan pheno dan pembuatan populasi. Diagram aplikasi diberikan dalam Gambar 1.

\section{A. Pembuatan Gen Batik Flora}

Suatu gen dibentuk dari proses analisis citra terhadap foto tanaman bunga yang dimasukkan oleh pengguna. Diagram pembuatan gen diberikan dalam Gambar 2. Hasil akhir dari tahap ini adalah gen motif flora yang bisa disimpan dalam database gen.

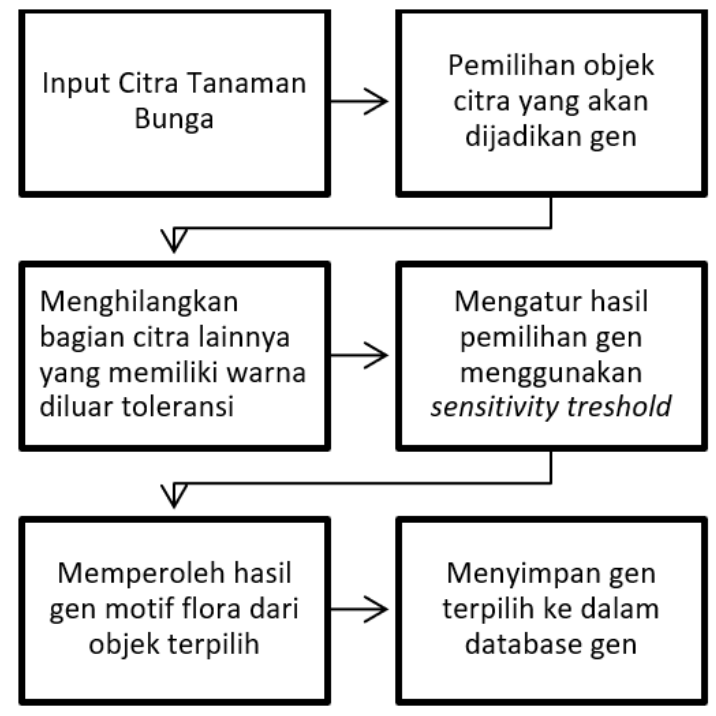

Gambar. 2 Diagram pembuatan gen

Analisis objek gen pada citra foto dilakukan dengan Langkah-langkah berikut ini.

- Membaca koordinat piksel dari objek yang dipilih pengguna

- Membaca nilai warna dari piksel tersebut

- Mengubah nilai semua piksel yang memiliki warna di luar range toleransi warna menjadi nol.

Proses dilanjutkan dengan melakukan pemotongan objek dengan menghitung koordinat batas objek melalui proses 8connected labelling berikut ini.

- Mengubah tipe gambar menjadi biner

- Mengenakan fungsi 8-connected labelling pada gambar biner

- Menghitung koordinat batas objek yang memiliki label yang sama dengan nomor label dari piksel yang dipilih pengguna

- Menggunakan koordinat batas objek untuk memotong objek.

\section{B. Pembuatan Pheno Batik Flora}

Pengguna diberi antarmuka untuk memilih satu atau beberapa gen yang dibuat menjadi sebuah pheno. Gen yang dipilih dapat dimodifikasi dengan menggunakan beberapa transformasi matematika seperti rotasi, translasi, dan perbesaran. Posisi dari suatu gen dapat diatur dalam area pheno dengan menggunakan model click-and-drop. Hasil pheno yang diperoleh dapat disimpan dalam database pheno. 


\section{Pembuatan populasi Batik Flora}

Pembuatan populasi dapat dilakukan dengan memilih satu atau beberapa pheno yang sudah dibuat pada panel kedua. Pengguna dapat memilih background kain dari file background yang dimiliki pengguna. Sistem menyediakan 6 (enam) buah layout untuk dipilih dalam replikasi pheno sesuai ukuran kain.

\section{Mekanisme Pengujian}

Pengujian sistem dilakukan untuk menjawab beberapa pertanyaan penelitian berikut ini.

- Apakah fitur warna dapat dipakai aplikasi untuk memperoleh gen objek motif bunga dari foto sesuai harapan pengguna

- Apakah 8-connected labelling dapat dipakai aplikasi untuk memotong batas gen sesuai dengan yang diharapkan, yaitu pada posisi yang tepat dengan batas yang benar

- Perbandingan dari objek gambar asli yang diturunkan menjadi gen, apakah bisa memenuhi tuntutan penelitian, seperti: bersih dari noise, utuh, tidak terputus, dan terpotong dengan baik.

- Apakah program aplikasi dapat memfasilitasi pengguna untuk membuat pheno dalam model click-and-drop dengan gen-gen yang dipilih.

- Apakah program bisa membentuk populasi sesuai layout yang disediakan.

\section{HASIL DAN PEMBAHASAN}

Program aplikasi ini dibangun dengan menggunakan software matlab R2017b. GUI Matlab dibangun dengan GUIDE beserta beberapa komponen UI yang digunakan dalam program, yaitu: push button, slider, dan listbox. Aplikasi dibuat dengan model tiga panel untuk mempermudah pengguna menggunakannya secara terstruktur. Tampilan dari aplikasi diberikan pada Gambar 3.

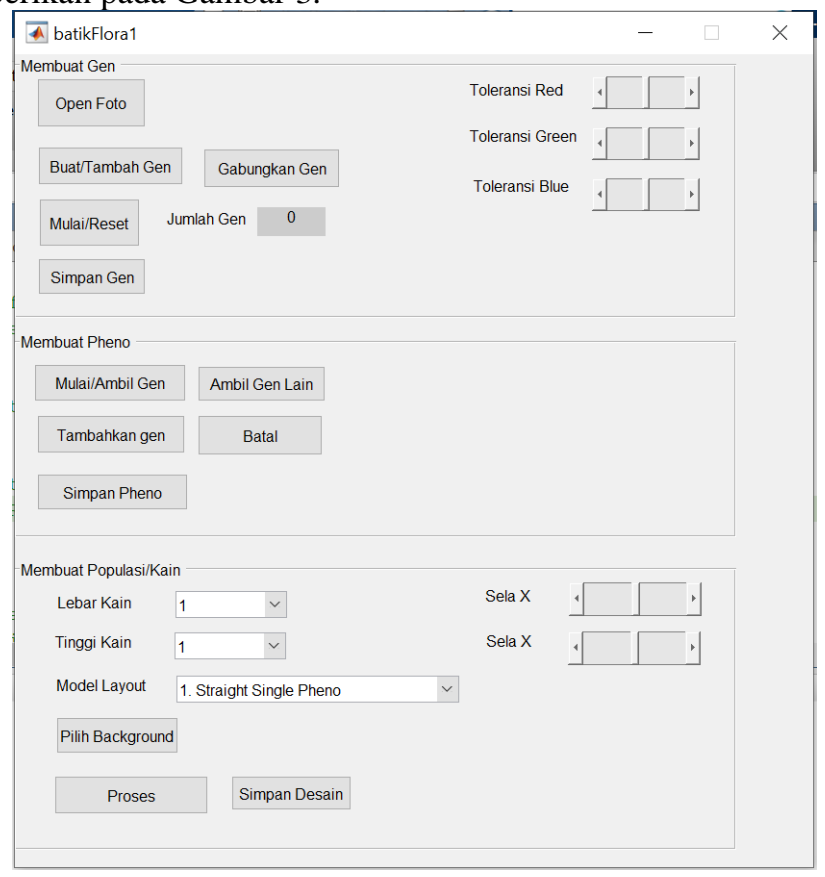

Gambar. 3 Tampilan aplikasi

\section{A. Panel 1. Membuat Gen}

Pada panel ini, pengguna dapat membuat gen penyusun motif dengan mengambil suatu objek dari foto atau gambar masukan pengguna. Dalam proses pemilihan objek dalam foto untuk dijadikan sebagai bahan pembuatan gen digunakan algoritma pengenalan warna, oleh sebab itu dalam panel ini disediakan tiga buah slider untuk pengaturan toleransi warna $\mathrm{R}($ Red $), \mathrm{G}($ Green $)$, dan $\mathrm{B}($ Blue $)$. Aplikasi akan memotong bagian objek terpilih secara otomatis dengan algoritma 8connected labelling. Pengambilan gen dilakukan dengan click objek yang dipilih pada gambar foto dengan menggunakan mouse. Pada panel ini disediakan beberapa tombol dengan penjelasan sebagai berikut:

- Tombol Open Foto, digunakan untuk memilih foto. Fungsi matlab yang dipakai untuk membaca image foto adalah: imread(file)

- Tombol Buat/Tambah Gen, untuk melakukan proses pembuatan bahan gen atau menambahkan gen baru. Untuk menangkap click mouse pada gambar digunakan fungsi matlab ButtonDownFcn pada handle figure. Untuk membaca koordinat piksel digunakan fungsi matlab get(Handle, 'CurrentPoint'). Dalam pembuatan gen dilakukan pengubahan nilai piksel dengan logika berikut ini

$\operatorname{Jika}(\operatorname{gambar}(x, y, R G B)<($ pikselTerpilih $(R G B)$-toleransi) atau

( $\operatorname{gambar}(x, y, R G B)>($ pikselTerpilih $(R G B)+$ toleransi $)$, maka: gambarHasilRGB $(x, y, R G B)=0$;

Pada citra hasil proses ini dilakukan pemotongan dengan menggunakan pelabelan pada tipe citra binernya. Fungsi matlab yang digunakan untuk mengubah citra dari tipe RGB ke biner adalah im2bw(citraRGB). Fungsi matlab untuk pelabelan menggunakan bwlabel(citraBiner)

- Tombol Gabungkan Gen, digunakan untuk menggabungkan gen sebelumnya dengan gen tambahan. Dalam proses penggabungan gen digunakan logika berikut:

$$
\begin{aligned}
& j i k a(\operatorname{gambarl}(x, y, R G B)>0), \text { maka } \\
& \operatorname{gambar} 2(x, y, R G B)=\operatorname{gambarl}(x, y, R G B)
\end{aligned}
$$

- Tombol Mulai/Reset, untuk memulai lagi proses pembuatan gen. Dengan menekan tombol ini maka jumlah gen yang akan dibuat akan direset kembali menjadi nol.

- Tombol Simpan Gen, untuk menyimpan gen yang dibuat ke dalam file gambar. Fungsi matlab yang digunakan untuk menyimpan gen adalah imsave(figure)

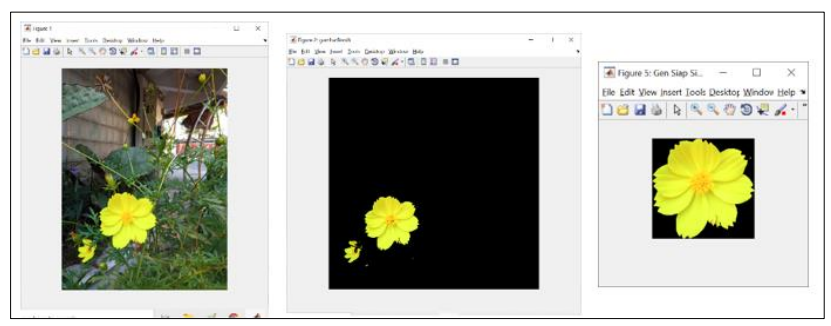

Gambar. 4 Proses pembuatan gen 
Proses pembuatan gen diberikan dalam Gambar 4. Dari gambar asli dilakukan proses pemilihan warna dengan toleransi yang diberikan. Pemotongan dilakukan oleh sistem dengan menggunakan fitur 8-connected labelling pada tipe citra biner nya.

Contoh hasil pengambilan gen dari foto diberikan dalam Tabel 1. Seperti yang ditampilkan dalam Tabel 1, pengambilan gen objek yang dipilih pengguna dapat dilakukan oleh aplikasi dengan baik menggunakan fitur warna. Gen yang diperoleh cukup bersih dari noise, dan utuh. Aplikasi berhasil memotong objek bunga dengan batas-batas dan posisi yang tepat.

TABEL I

CONTOH HASIL PENGAMBILAN GEN DARI Foto ASLI

\begin{tabular}{|c|c|c|}
\hline \multirow[t]{2}{*}{ No } & \multicolumn{2}{|c|}{ Pengambilan gen } \\
\hline & Foto Asli & Gen yang diambil \\
\hline 1 & & \\
\hline 2 & & \\
\hline 3 & & \\
\hline 4 & & \\
\hline 5 & & \\
\hline 6 & $97 \mathrm{~V}$ & \\
\hline
\end{tabular}

\section{B. Panel 2. Membuat Pheno}

Pada panel ini, pengguna dapat membuat pheno atau motif batik flora yang bisa disusun dari satu atau beberapa gen. Aplikasi menyediakan papan grid untuk menyusun letak gengen yang diambil dari data gen yang sudah dibuat sebelumnya oleh pengguna. Gen diletakkan oleh pengguna dengan cara click mouse pada posisi yang diinginkan. Pada pemrograman panel digunakan fungsi-fungsi pengaturan koordinat letak gen. Dalam panel ini disediakan beberapa tombol berikut ini:

- Tombol Mulai/Ambil Gen, digunakan untuk memulai pembuatan pheno dengan mengambil sebuah gen dan meletakkan pada papan grid.

- Tombol Ambil Gen Lain, digunakan untuk mengambil gen lain yang berbeda yang ingin ditambahkan dalam pheno yang dibuat

- Tombol Tambahkan gen, digunakan untuk menambahkan gen yang sama dengan gen sebelumnya ke dalam pheno yang ada

- Tombol Batal, untuk membatalkan langkah terakhir dalam pembuatan pheno, misalnya tidak jadi menambahkan pheno pada posisi tertentu dan ingin menaruhnya pada posisi yang lainnya.

- Tombol Simpan Pheno, digunakan untuk menyimpan pheno yang dibuat dalam file gambar.

Setelah proses pengaturan pheno selesai dilakukan, maka aplikasi akan melakukan pemotongan pheno secara otomatis dengan mengacu pada koordinat terkecil, koordinat terbesar, dan ukuran masing-masing gen yang disusun. Proses pembuatan pheno oleh pengguna diberikan dalam Gambar 5.

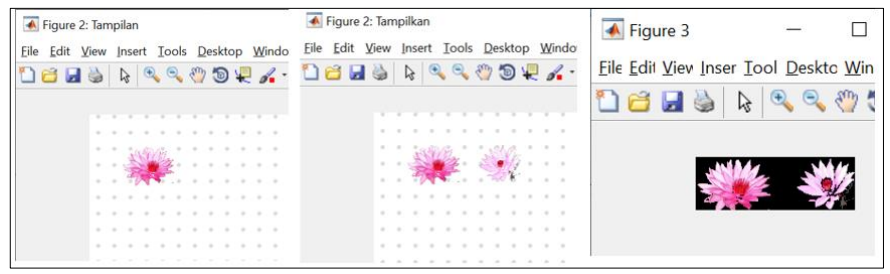

Gambar. 5 Proses pembuatan pheno

TABEL II

CONTOH Hasil PEMBUATAN PHENO

Gen yang
dipakai




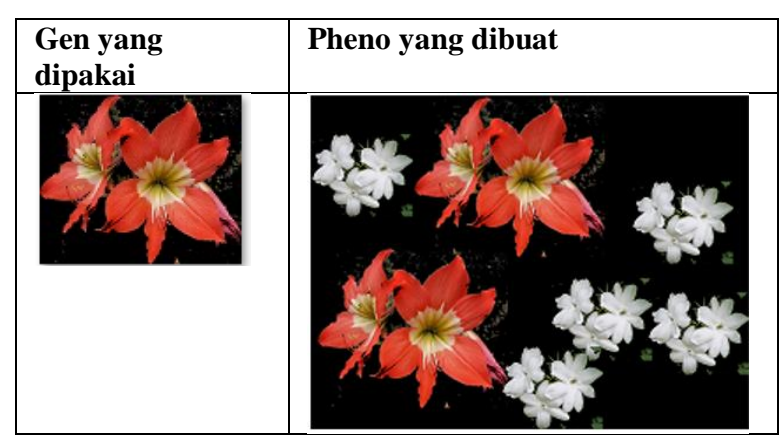

Contoh pembuatan pheno dari gen yang dipakai diberikan pada Tabel 2. Seperti contoh yang diberikan dalam Tabel 2, aplikasi berhasil memfasilitasi pengguna untuk membuat pheno dari beberapa gen yang telah dibuat dengan menggunakan model click-and-drop. Aplikasi juga dapat memotong pheno dengan batas-batas yang tepat.

\section{Panel 3. Membuat Populasi}

TABEL III

CONTOH HASIL PEMBUATAN POPULASI

\begin{tabular}{|c|c|c|}
\hline No & $\begin{array}{l}\text { Pilihan } \\
\text { Layout }\end{array}$ & Populasi yang dibuat \\
\hline 1 & $\begin{array}{l}\text { Straight } \\
\text { Single } \\
\text { Pheno }\end{array}$ & 8 ard \\
\hline 2 & $\begin{array}{l}\text { Straight } \\
\text { Double } \\
\text { Pheno } \\
\text { Horisontally }\end{array}$ & 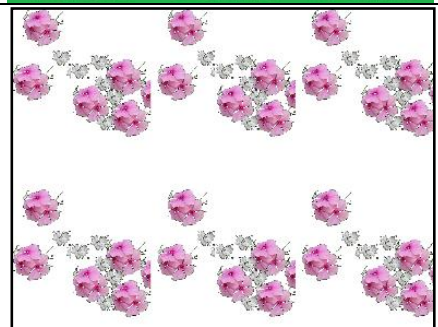 \\
\hline 3 & $\begin{array}{l}\text { Straight } \\
\text { Double } \\
\text { Pheno } \\
\text { Vertically }\end{array}$ & 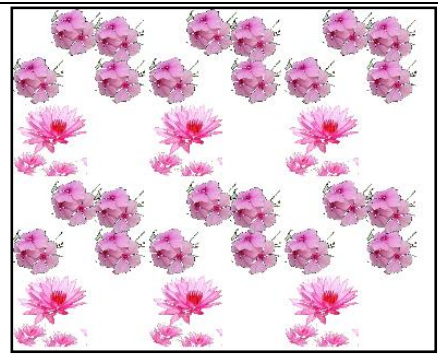 \\
\hline 4 & $\begin{array}{l}\text { Halfdrop } \\
\text { Single } \\
\text { Pheno }\end{array}$ & 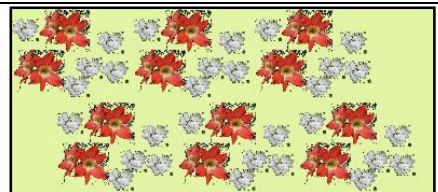 \\
\hline
\end{tabular}

\begin{tabular}{|c|c|c|}
\hline No & $\begin{array}{l}\text { Pilihan } \\
\text { Layout }\end{array}$ & Populasi yang dibuat \\
\hline 5 & $\begin{array}{l}\text { Halfdrop } \\
\text { Double } \\
\text { Pheno }\end{array}$ & 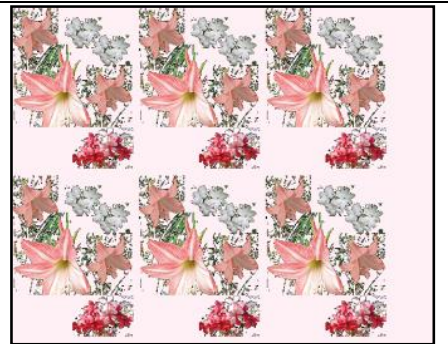 \\
\hline 6 & $\begin{array}{l}\text { Cross } \\
\text { Double } \\
\text { Pheno }\end{array}$ & 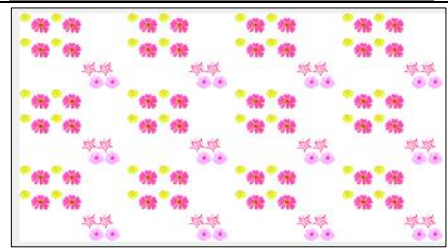 \\
\hline
\end{tabular}

Pengguna dapat membuat desain kain batik flora dengan memilih ukuran kain berupa lebar kain dan tinggi kain. Pengguna diminta untuk memilih file background dari kain batik sehingga sesuai dengan rencana desain. Pengguna diminta memilih model layout yang single pheno atau yang model double pheno dari daftar pilihan yang disediakan oleh aplikasi. Jumlah pheno yang harus diambil pengguna menyesuaikan dengan pilihan layout. Sistem menyediakan 6 jenis layout dengan contoh desain yang dihasilkan diberikan dalam Tabel 3. Aplikasi berhasil membuat populasi sesuai layout yang dipilih. Model layout dibuat dengan menggunakan prinsip desaian layout standar yang dipakai di industri.

Dari hasil pembuatan aplikasi desain, maka dapat diperoleh berbagai macam kreasi desain kain batik yang terus menerus baru. Hal ini disebabkan pengambilan foto citra flora bisa dilakukan oleh pengguna setiap saat dengan variasi tanaman bunga yang bisa diperoleh di sekitar pengguna. Semakin banyak foto yang digunakan untuk membuat gen akan semakin memperbanyak variasi gen pembentuk motif pheno. Pengaturan tata letak gen dalam pembuatan pheno dengan model interaktif juga memperkaya desain motif batik flora. Dengan menggunakan model pemrograman panel, maka program masih dapat dikembangkan untuk menambah modelmodel layout selain layout yang sudah dibuat oleh aplikasi. Program aplikasi ini masih didesain dengan berdasarkan ide dari peneliti saja.

\section{KESIMPULAN}

Sistem Desain Batik Flora yang dibangun mampu membuat desain motif batik flora dengan berbagai macam kreasinya. Pemanfaatan fitur warna untuk mengenali objek bunga dan memisahkannya dari warna latar belakang dalam foto berhasil dilakukan seperti yang ditunjukkan dalam contoh hasil desain. Variasi kreasi desain sangat bergantung dari usaha pengguna dalam mencari foto-foto objek bunga di sekitar pengguna. Variasi motif juga bergantung dari kemampuan pengguna dalam mengatur tata letak gen yang disusun menjadi pheno. Penyediaan 6 macam layout desain kain batik pada sistem dapat memberikan variasi desain batik flora. Penambahan model layout dapat dilakukan dengan pengembangan sistem lebih 
lanjut. Program masih perlu dikembangkan untuk bisa memenuhi keinginan desainer batik. Penelitian lanjutan dapat dilakukan untuk melakukan evaluasi terhadap antar muka aplikasi dan redesain aplikasi menggunakan pendekatan berpusat pada pengguna, yaitu desainer batik.

\section{UCAPAN TERIMA KASIH / ACKNOWLEDGMENT}

Peneliti mengucapkan terima kasih kepada LPPM UKDW yang telah memberikan dana untuk pelaksanaan penelitian terapan ini. Kedua penulis dalam artikel ini adalah peneliti sekaligus pengembang sistem yang dibuat.

\section{REFERENSI}

[1] S. M. Metev and V. P. Veiko, Laser Assisted Microtechnology, 2nd ed., R. M. Osgood, Jr., Ed. Berlin, Germany: Springer-Verlag, 1998.

[2] UNESCO, "Decision of the Intergovernmental Committee: 4.COM 13.44," 30 January 2019. [Online]. Available: https://ich.unesco.org/en/Decisions/4.COM/13.44.

[3] D. P. R. Balai Besar Kerajinan \& Batik, Batik, Citra Tradisi Indonesia Kumpulan Motif Batik Tradisional Yogya dan Solo, Yogyakarta: Panitia Pameran Produksi Indonesia 2009, 2009.

[4] [4] D. Nurcahyanti and T. B. Affanti, "Pengembangan Desain Batik Kontemporer Berbasis Potensi Daerah dan Kearifan Lokal,” Jurnal Sosioteknologi, vol. 17, no. 3, pp. 391-402, 2018.

[5] W. Hapsari and N. A. Haryono, "Sistem Interaktif Desain Batik Truntum," in Research Fair UNISRI, Surakarta, 2018.

[6] W. Hapsari and N. A. Haryono, "Pembangunan Sistem Desain Batik Parang dengan Kurva Bezier,” Dinamika Kerajinan dan Batik, vol. 37, no. 2, pp. 127-144, 2020.

[7] P. D. Kusuma, "Fibrous Root Model In Batik Pattern Generation," Journal of Theoretical and Applied Information Technology, vol. 95, no. 14, pp. 3260-3269, 2017.

[8] P. D. Kusuma, "Simplified Coral Modeling In Batik Pattern Generation," Journal of Theoretical and Applied Information Technology, vol. 96, no. 10, pp. 3102-3115, 2018.

[9] P. D. Kusuma, "Graph Based Simplified Crack Modeling In Batik Pattern Generation," Journal of Theoretical and Applied Information Technology, vol. 95, no. 19, pp. 5035-5046, 2017.

[10] M. Z. W. P. a. X. L. J. Lv, "Interactive Genetic Algorithm Oriented toward the Novel Design of Traditional Patterns," Information, vol. 10, no. 2, p. 36, 2019

[11] W. P. Z. L. J Lv, "Method of Batik Simulation Based on Interpolation Subdivisions," JOURNAL OF MULTIMEDIA, vol. 9, no. 2, p. 286 2014.

[12] Y. Hariadi, M. Lukman and A. H. Destiarmand, "Batik Fractal: Marriage of Art and Science," ITB J. Vis. Art \& Des., pp. 84-93, 2013.

[13] N. Margried, "Batik Fractal Community: Creative Engagement through Technology," Procedia - Social and Behavioral Sciences, pp. 214-222, 2015.

[14] Q. Yuan, J. Lv and H. Huang, “Auto-Generation Method of Butterfly Pattern of Batik Based on Fractal Geometry," International Journal of Signal Processing, Image Processing and Pattern Recognition, vol. 9, pp. 369-392, 2016.

[15] W. N. U. Bastaman and T. N. I. Fadliani, "Pengembangan Motif Bordir Kerancang Tasikmalaya Dengan Software JBatik," Dinamika Kerajinan dan Batik, vol. 37, no. 2, pp. 135 - 146, 2020.

[16] P. D. Kusuma, "Interaction Forces-Random Walk Model In Traditional Pattern Generation," Journal of Theoretical and Applied Information Technology, vol. 95, no. 14, pp. 3294-3302, July 2017.

[17] P. Arsiwi and M. A. Wibisono, "Pengembangan Model Desain Motif Batik Tulis Hand-Drawn Berbasis Bezier Curve," in Seminar Nasional Teknik Industri Universitas Gadjah Mada, Yogyakarta, 2016.

[18] W. Hapsari and N. A. Haryono, "Pembuatan Sistem Desain Batik dengan Komputasi Matematis," in Prosiding Semnastik , Palembang, 2018

[19] P. D. Kusuma, "Modified Sine Wave Based Model In Madurese Batik Pattern Generation," Journal of Theoretical and Applied Information Technology, vol. 97, no. 23, pp. 3557-3569, 2019.
[20] P. Supriono, Ensiklopedia The Heritage of Batik : Identitas Pemersatu Kebanggan Bangsa, Yogyakarta: Andi Offset, 2016.

[21] K. Susmitha, S. G. Tejaswi, K. L. Kala, K. P. Pranutha and S. Tirumalasetty, "Classifying Deviations in Medical Microscopic Images Using Evolutionary Analysis," Iconic Research and Engineering Journals, vol. 1, no. 9, p. 233, 2018

[22] K. Anwar and S. Setyowibowo, "Segmentasi Kerusakan Daun Padi pada Citra Digital,” Jurnal Edukasi dan Penelitian Informatika, vol. 7, no. 1, pp. 39-43, 2021.

[23] A. Desiani, D. A. Zayanti, R. Primartha, F. Efriliyanti and N. A. C. Andriani, "Variasi Thresholding untuk Segmentasi Pembuluh Darah Citra Retina," Jurnal Edukasi dan Penelitian Informatika, vol. 7, no. 2, pp. 255-262, 2021.

[24] R. S. A. Zneit, Z. Alqadi and M. A. Zalata, "Procedural Analysis of RGB Color Image Objects," IJCSMC-Int. Journal of Computer Science \& Mobile Computing, vol. 6, no. 1, pp. 197-204, 2017.

[25] M. A. Hamdan, Z. A. Alqadi and B. M. Subaih, "A Methodology to Analyze Objects in Digital Image using Matlab," IJCSMC - Int. Journal of Computer Science and Mobile Computing, vol. 5, no. 11, pp. 21-28, 2016.

[26] V. S. Pathania, V. Thakur and A. Mishra, "Shape Enhancement of Clustered Seeds using Edge Detection Algorithm," International Journal Of Scientific \& Engineering Research, vol. 7, no. 7, pp. 902-907, 2016.

[27] P. Shanmugavadivu and A. Shanthasheela, "Convolution Based Composite Edge Detector for Gray-Scale and Colour Images," International Journal of Scientific \& Engineering Research, vol. 7, no. 3, pp. 897-900, 2016.

[28] J. Vijayakumar and L. J. Durai, "A Review and Performance Analysis of Image Edge Detection Algorithms," International Journal on Future Revolution in Computer Science \& Communication Engineering, vol. 3, no. 12, pp. 397-401, 2017. 